\title{
Relationship between Capital Structure and Performance Evidence based on Information Technology Industry
}

\author{
Wang Chunhua \\ Business School \\ Beijing Wuzi University \\ Beijing, China \\ wangchunhua@bwu.edu.cn
}

\author{
Song Meiyan \\ Business School \\ Beijing Wuzi University \\ Beijing, China \\ songmeiyan838@sina.com
}

\begin{abstract}
In recent years, capital structure and business performance is researched by many domestic and foreign scholars in-depth. Information technology industry is as a pillar industry and a highly growing industry with a huge potential market supported by our government; research of capital and performance focuses on manufacturing, banking, real estate and other industries in China has been done, so capital structure and performance of the Information Technology Industry is researched which is essential.(Abstract)
\end{abstract}

Keywords- Capital structure, Operating performance, Information technology industry(key words)

\section{I.INTRODUCTION}

Since Modigliani\&Miller (1958) proposed the famous MM theorem, about how to choose the capital structure and whether the capital structure and financial decisions affect the value of the company has been constantly studied and discussed in the academic. So far, the main theories of capital structure has formed including the trade-off theory, pecking order theory, the financing preference theory and Asymmetric information theory etc.

Welch (2007) and Frank\&Goyal (2008) pointed out that, if using micro data to examine the capital structure theory, profitability and growth of firm level variables and the degree of product market competition of industry level variables have possible interaction and mutual influence with financial leverage, at the same time, the explanatory variables may also appear omissions or error measurement that makes model generate endogenous problem and cause the coefficient estimates biased and inconsistent

Xiao Zuoping (2004) studies the capital structure from the dynamic characteristics factors and finds that transaction cost is an important influencing factor. Asset tangibility and size are positive correlated to the financial leverage, while growth and liquidity are negative correlated to the financial leverage. Berger (2006) thinks that enterprise debt rate can reduce the agency cost associated with the external equity.

Chen Deping and Chen Yongsheng (2011) found that there is a positive correlation between the capital structure and profitability and collateral value of assets while debt paying ability and non-debt tax shield are negative correlated with the capital structure.

Corporate performance is influenced by capital structure, corporate governance structure etc. In addition, corporate performance is also affected by the factors of firm characteristics such as company growth, company size and risk etc. In the empirical study of the relationship between capital structure and corporate performance, researchers usually put the factors of firm characteristics as control variables.

The existing domestic research results about the choice of capital structure mainly concentrated on three aspects: one, from a static point of view to examine the relationship between capital structure of listed companies and its determinants, Shen Weitao and Ye Xiaoming (2004), Tong Pan and Lu Zhengfei (2005) studied on the relationship between capital structure and company size, growth, profitability, non-debt tax shields, collateral value of assets,economic value-added and other factors in detail; two, by examining the trade-off theory and optimal financing order theory, researching the financing decisions of listed companies, Chen Xiao and Shan Xin (1999), Huang Shaoan and Zhang Gang (2001) found that China's listed companies have a strong preference for equity financing, Zhang Jun (2005) believes that the listing Corporation's equity and debt have a financing excessive tendency, Wu Liansheng and Yue Heng (2006) found that the choice of capital structure of the listed companies meet the trade-off theory; three, based on interdisciplinary, researching the choose of capital structure of the listed companies, Jiang Fuxiu and Liu Zhibiao (2005), Deng Jianqin and Zhu Wuxiang (2006) found that the relationship between the capital structure and the product market competition intensity are positive correlated.

Through the related literature at home and abroad we found:the relationship between corporate performance and capital structure has not formed a consistent conclusion at this stage. Therefore, this paper will analyze the relationship between corporate performance and capital structure, in order to provide advice to study on the relationship between performance and capital structure.

\section{II.SAMPLE DATA}

The data in this paper are from CSMAR database of Chinese listed companies researched and developed by GTA Corporation, and information technology listed companies in Shanghai and Shenzhen Stock Exchange are sample, 6 years (2005-2011) financial data are chosen, and with the help of Excel and SPSS statistical software to accomplish the empirical study. In order to ensure the 
accuracy and objectivity, the samples are selected according to the principles as follows:

- To avoid the impact of new shares, A-share listed companies are selected before the January 1, 2005, so the listed companies' behaviors are ensured more mature.

- To avoid the impact of outliers, ST and PT companies and anomalous performance of company are removed, and 64 listed companies of the information technology industry as samples are selected.

- To ensure data true and reliable, financial data are audited by certified public accountants, we believe that is true and reliable, and the information does not affect the quality of the problem.

\section{III.EMPIRICAL ANALYSIS}

\section{A. Selection of indicators}

Performance indicators of the company include the financial indicators and non-financial indicators. Financial indicators has been adopted and will have been adopted in future also to be the most widely, because the company's long-term goal is almost always purely financial in nature, and financial performance evaluation indicators directly link up the company's financial goals. At the same time, there are many scholars reflecting the financial indicators of company's performance, and this paper draw on previous research, and gradually filter through factor analysis, and select 13 principal component from a number of indicators to analyze, and rotate loading matrix to get six main factors and to be named, table 1 :

Table 1 Main factors named

\begin{tabular}{|c|c|c|}
\hline Main factors & $\begin{array}{l}\text { Name the main } \\
\text { factors }\end{array}$ & Variable name \\
\hline \multirow{3}{*}{$\mathrm{X} 1$} & \multirow{3}{*}{ Profitability } & ROE \\
\hline & & Total assets Net profit margin \\
\hline & & Sales margin \\
\hline \multirow{2}{*}{$\mathrm{X} 2$} & \multirow{2}{*}{ Operating capacity } & Equity turnover \\
\hline & & Mobile Asset Turnover \\
\hline \multirow{2}{*}{$\mathrm{X} 3$} & \multirow{2}{*}{ Solvency } & Current Ratio \\
\hline & & Equity/debt \\
\hline \multirow{2}{*}{$\mathrm{X} 4$} & \multirow{2}{*}{ Growth } & Growth rate of total assets \\
\hline & & Rate of capital accumulation \\
\hline \multirow[b]{2}{*}{$\mathrm{X} 5$} & \multirow[b]{2}{*}{ R \& D capabilities } & $\begin{array}{c}\text { Intangible assets/ total assets } \\
\text { 占总资产比率 }\end{array}$ \\
\hline & & $\begin{array}{c}\text { (Intangible assets }+\mathrm{R} \& \mathrm{D} \\
\text { expenditures) } / \\
\text { Revenue }\end{array}$ \\
\hline X6 & $\begin{array}{c}\text { Product } \\
\text { uniqueness }\end{array}$ & $\begin{array}{c}\text { Operating costs / Revenue } \\
\text { 营业收入 }\end{array}$ \\
\hline
\end{tabular}

\section{B. Related assumptions to be proposed}

The relationships between capital structure and operating performance of listed companies of the information technology industry are proposed to make the following assumptions:

- The relationship is negative correlation between company's capital structure and profitability. If profitability is stronger the company may earn more funds to meet the needs of the company, therefore the company does not need too much external financing to meet the fund need of producing and operating. Hence profitability and capital structure should be negative.

- The relationship is positive correlation between company's capital structure and asset operating capacity. The company with stronger operating capacity means it is with the higher efficiency managing assets, the better financial situation of enterprises and the greater anti-risk ability, so it can be the more qualified company to get debt.

- The relationship is negative correlation between company's capital structure and solvency. The solvency of the company is stronger that means the company's debt is less and the company's financial risk is smaller, so the company's capital structure and solvency should be negative.

- The relationship is positive correlation between company's capital structure and growth. The strong growth implies the company with good development prospects, so it has generally a strong solvency for more debt financing to avoid shareholders controlling and diluting earnings per share while the company own financial can't meet for the need of fast-growing development,

- The relationship is positive correlation between company's capital structure and R \& D capabilities. If the company possesses strong R \& D capability, more capital to support research and innovation and more debt to resolve the shortage of funds are required, so $\mathrm{R} \& \mathrm{D}$ capabilities and capital structure should be negatively.

- The relationship is negative correlation between company's capital structure and product uniqueness. The uniqueness of the company's products is stronger while the company should have less debt.

\section{IV.REGRESSION ANALYSIS}

The factor scores of the 6 composite indicators are obtained as independent variables after factor analysis, and the regression equation is established with 6 composite indicators and capital structure. Multiple linear regression model is as follows:

$$
\mathrm{Y}=\beta_{0}+\beta_{1} \mathrm{X}_{1}+\beta_{2} \mathrm{X}_{2}+\cdots \beta_{\mathrm{i}} \mathrm{X}_{\mathrm{i}}+\xi
$$

In the formula: $Y$ represents the capital structure; $\beta$ represents the regression coefficient $(i=0,1,2,3,4,5,6)$; $\mathrm{X}_{\mathrm{i}}$ represents the "i" principal component factors that derived from the factor analysis; $\xi$ is the error.

Using Regression-Linear regression module (Enter) method of SPSS software, the asset-liability ratio "Y" is 
as the capital structure of the variable to execute regression. The result is shown in table 2 , table 3 , table 4 :

Table 2 Model Summary(b)

\begin{tabular}{|c|c|c|c|c|c|}
\hline Model & $\mathrm{R}$ & $\begin{array}{c}\mathrm{R} \\
\text { Square }\end{array}$ & $\begin{array}{c}\text { Adjusted } \\
\mathrm{R} \text { Square }\end{array}$ & $\begin{array}{c}\text { Std. Error of } \\
\text { the Estimate }\end{array}$ & $\begin{array}{c}\text { Durbin-W } \\
\text { atson }\end{array}$ \\
\hline $\begin{array}{c}\text { Asset-liabili } \\
\text { ty ratio }\end{array}$ & 0.758 & 0.574 & 0.566 & 0.100 & 2.001 \\
\hline
\end{tabular}

Table 3 ANOVA(b)

\begin{tabular}{|c|c|c|c|c|c|c|}
\hline \multicolumn{2}{|c|}{ Model } & $\begin{array}{c}\text { Sum of } \\
\text { Squares }\end{array}$ & df & $\begin{array}{c}\text { Mean } \\
\text { Squar } \\
\text { e }\end{array}$ & F & Sig. \\
\hline \multirow{3}{*}{$\begin{array}{c}\text { Asset } \\
\text {-liabil } \\
\text { ity } \\
\text { ratio }\end{array}$} & Regression & 4.230 & 6.000 & 0.705 & 70.346 & \multirow{2}{*}{0.000} \\
\cline { 2 - 6 } & Residual & 3.137 & 313.000 & 0.010 & & \\
\cline { 2 - 6 } & Total & 7.367 & 319.000 & & & \\
\hline
\end{tabular}

Table 4 Coefficients (a)

\begin{tabular}{|c|c|c|c|c|c|c|}
\hline \multirow{2}{*}{ Model } & \multicolumn{2}{|c|}{$\begin{array}{c}\text { Unstandardized } \\
\text { Coefficients }\end{array}$} & $\begin{array}{c}\text { Standa } \\
\text { rdized } \\
\text { Coeffic } \\
\text { ients }\end{array}$ & \multirow{2}{*}{$\mathrm{t}$} & \multirow{2}{*}{ Sig. } \\
\cline { 2 - 7 } & $\mathrm{B}$ & Std. Error & Beta & & \\
\hline \multirow{4}{*}{$\begin{array}{c}\text { Asse } \\
\mathrm{t}-\text {-lia } \\
\text { bilit } \\
\mathrm{y} \\
\text { ratio }\end{array}$} & $\begin{array}{c}\text { Constan } \\
\mathrm{t}\end{array}$ & 0.454 & 0.006 & & 81.100 & 0.000 \\
\cline { 2 - 7 } & $\mathrm{X} 1$ & -0.038 & 0.006 & -0.252 & -6.823 & 0.000 \\
\cline { 2 - 7 } & $\mathrm{X} 3$ & -0.102 & 0.006 & -0.672 & -18.22 & 0.000 \\
\cline { 2 - 7 } & $\mathrm{X} 4$ & -0.018 & 0.006 & -0.118 & -3.202 & 0.002 \\
\cline { 2 - 7 } & $\mathrm{X} 6$ & -0.026 & 0.006 & 0.172 & -4.650 & 0.000 \\
\hline
\end{tabular}

\section{Regression Results Analysis}

The regression equation is obtained based on the above analysis:

$$
\begin{gathered}
\mathrm{Y}=0.454-0.038 \mathrm{X} 1+0.017 \mathrm{X} 2-0.102 \mathrm{X} 3+0.009 \mathrm{X} 4- \\
0.018 \mathrm{X} 5-0.026 \mathrm{X} 6+0.006
\end{gathered}
$$

The indicators are is compatible hypotheses except the empirical results of $\mathrm{R} \& \mathrm{D}$ capabilities X5. To the indicator of $\mathrm{R} \& \mathrm{D}$ capabilities, this paper hypothesizes there is a positive correlation between the indicator and capital structure, but the result of empirical research is negative, probably because the information technology industry's main competitiveness come from the company's innovation capability, and the growing information technology industry with high speed need a lot of money invested to get a large number of precision instruments to innovate and a great deal of manpower and material for research and innovation, but the cash-flow from day-to-day running of the company cannot meet the needs of the company's development, so the debt or equity financing are needed, which affect the company's financing structure. However the listed companies of information technology industry in China are more likely equity financing rather than debt financing when the situation lies in the shortage of funds, which further led to a negative correlation between research and development capabilities and capital structure.

\section{Discussion of empirical results}

The empirical results show company growth is less influential to the company's capital structure, so the factors will be explained except the indicator of the company growth.

- The relationship is negative correlation between total debt ratio and the profitability of company.

From the results of the empirical analysis, the profitability of listed companies of the information technology industry is the most important factor which affect total debt ratio as a negative factor. In China, the government plays a certain role in the company's growth and development. When the government considers to promote economic development, employment and other issues, it will increase efforts to support the company of the industry with innovation and high investment especially, such as the information technology industry would be given strong support so that shareholders would not play significant role to constraint the debt, which would lead to excessive investment and profitability of the company not to be ideal. That could explain the negative relationship between debt ratio and profitability in the information technology industry.

- The relationship is positive correlation between total debt ratio and the operational capacity.

Well-behaved operational capacity of the company means it has a higher turnover rate of working capital and running more normal. what's more, the higher rate of cash flow makes the company uses high-speed working capital to meet the needs of the company for capital instead of debt financing or equity financing when there are shortages, so there is positive relationship between operational capacity and the company's total debt ratio.

- The relationship is negative correlation between total debt ratio and the solvency of company.

To information technology companies which are in the fast growing and focus on research and development, there will be more flexible investment in the future, so if the companies excessively use external debt financing, the high agency costs of debt would be given. Therefore, even if the solvency of these companies is better, the investment opportunities also would be influenced. For the reason, managers will carefully select lower liabilities; at the same time information technology companies are more likely equity financing in China. Both of them may cause the total debt rate is negative to solvency.

- The relationship is negative correlation between total debt ratio and the solvency, product uniqueness of company. 
Listed companies of information technology industry constantly pursue innovation which requires a lot of financial and material resources as a backing. When information technology companies are in the shortage of funds in China they will consider equity financing firstly, rather than debt financing, especially for those with good company performance, which are easier to use their equity financing. As a result $R \& D$ capability is negative to total debt ratio in the information technology industry.

Product uniqueness is negative to total debt ratio. If there is a relatively poor operating performance for listed companies of the information technology industry, equity financing is not readily available, and the company will take measure of bank loans, meanwhile the costs of the company's current liabilities will increase. Under this situation, when companies are without the benefits of debt financing and hard to convert the research and innovation to corporate profits, there will be a negative impact on company's operating performance, and lead to a negative affecting on companies operation. Therefore research and development capabilities are negative to product uniqueness in the information technology industry.

\section{REFERENCES}

[1] Booth Laurence, et al,"Capital Structure in Developing Countries,'J. Journal of Finance, vol.56, 2001,pp.87-130.

[2] J.K. Wald,"How firm characteristics affect capital structure: An international comparison,"J. Journal of Financial Research, February pp.161-187. 